Structural Prevention of Ethnic Violence 
This page intentionally left blank 


\section{Structural Prevention of Ethnic Violence}

Christian P. Scherrer

Ethnic Conflicts Research Project (ECOR)

The Netherlands

and

Hiroshima Peace Institute

Hiroshima City University

Japan

Foreword by Johan Galtung 


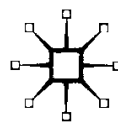

(c) Christian P. Scherrer 2002

Foreword (๐) Johan Galtung 2002

Softcover reprint of the hardcover 1st edition 2002 978-0-333-75206-7

All rights reserved. No reproduction, copy or transmission of this publication may be made without written permission.

No paragraph of this publication may be reproduced, copied or transmitted save with written permission or in accordance with the provisions of the Copyright, Designs and Patents Act 1988, or under the terms of any licence permitting limited copying issued by the Copyright Licensing Agency, 90 Tottenham Court Road, London W1T 4LP.

Any person who does any unauthorised act in relation to this publication may be liable to criminal prosecution and civil claims for damages.

The authors have asserted their rights to be identified as the authors of this work in accordance with the Copyright, Designs and Patents Act 1988.

First published 2002 by

PALGRAVE MACMILLAN

Houndmills, Basingstoke, Hampshire RG21 6XS and

175 Fifth Avenue, New York, N.Y. 10010

Companies and representatives throughout the world

PALGRAVE MACMILLAN is the global academic imprint of the Palgrave Macmillan division of St. Martin's Press, LLC and of Palgrave Macmillan Ltd. Macmillan ${ }^{\circledR}$ is a registered trademark in the United States, United Kingdom and other countries. Palgrave is a registered trademark in the European Union and other countries.

ISBN 978-1-349-41268-6 ISBN 978-0-230-59797-6 (eBook)

DOI $10.1057 / 9780230597976$

This book is printed on paper suitable for recycling and made from fully managed and sustained forest sources.

A catalogue record for this book is available from the British Library.

Library of Congress Cataloging-in-Publication Data

Scherrer, Christian P.

Structural prevention of ethnic violence / by Christian P. Scherrer. p. cm.

'Ethnic Conflicts Research Project (ECOR), the Netherlands'. Includes bibliographical references and index.

ISBN 978-1-349-41268-6 (cloth)

1. Ethnic conflict-Prevention. 2. Political violence-Prevention.

3. Conflict management. 4. Peace. I. Title

GN496 .S37 2002

305.8-dc21

2001053260

$\begin{array}{rrrrrrrrrr}10 & 9 & 8 & 7 & 6 & 5 & 4 & 3 & 2 & 1 \\ 11 & 10 & 09 & 08 & 07 & 06 & 05 & 04 & 03 & 02\end{array}$


To the threatened people and peoples of this world 
This page intentionally left blank 


\section{Contents}

List of Tables

Foreword by Johan Galtung

Preface

xiii

List of Abbreviations

xxi

Introduction: Ethnos, Nations, Ethno-nationalism and Conflict

Minority conflicts? an attempt at definition

The concept of the ethnos

The concept of nationality

Politicization of the ethnic

1 Contemporary Mass Violence $\quad 10$

$\begin{array}{lll}1.1 & \text { Ethnicity and mass violence } & 11\end{array}$

$\begin{array}{ll}1.2 \text { Non-Clausewitzean wars and mass violence } & 15\end{array}$

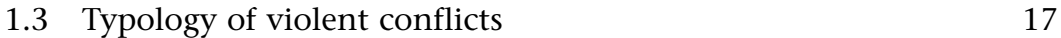

1.4 Indexes of contemporary violent conflicts 23

1.5 Trends and perspectives 39

2 Approaches to Identifying and Dealing with 46 Violent Conflicts

2.1 Legitimate opposition in the unequal struggle 49 for survival

2.2 Reorientation of peace and conflict research 55

$\begin{array}{lll}2.3 & \text { Current state of peace research and search } & 61\end{array}$ for peace: deficiencies and developments

2.4 The tasks of peace research in the twenty-first century 63

2.5 General heuristic maxims for research into 65 ethnicity and conflict

2.6 The need for applied research methods 69

2.7 Development of appropriate concepts and instruments $\quad 70$

$\begin{array}{ll}2.8 \text { The challenges of building peace } & 71\end{array}$ 
3 Peaceful Conflict Settlement, Go-between Facilitation and the Timing of Responses to Conflict

3.1 Dispute settlement as an instrument of international politics

3.2 Third party or go-between?

3.3 The process of escalation, timing and type of responses

3.4 Debate about complex political emergencies

3.5 Low chances for the peaceful settlement of protracted conflicts

4 Autonomy, Free Association and Self-governance

4.1 The fundamental right to self-determination in relation to international law

4.2 The concept of autonomy and the minorities question in Europe

4.3 Transfer of sovereignty rights via bilateral agreements

4.4 Self-government: elements and evaluation criteria

4.5 Examples of self-governance among indigenous peoples in America

4.6 Constructive structural elements for multi-ethnic states

4.7 Federation, decentralization and self-governance

4.8 Europe of the regions versus EU super-state?

4.9 Racism, xenophobia and discrimination in Europe 159

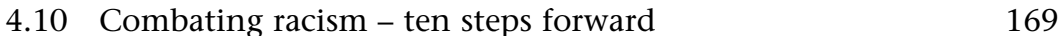

4.11 Enlargement of the European Union: dangers and gains 181

4.12 The search for a new configuration for Europe: obstacles towards a European federation

5 Nationality Policy as Violence Prevention: a Brief Comparison of Large States

5.1 Self-government: cases for comparison

5.2 The USSR model and what remains of it

5.3 China: a large multinational-style state

5.4 India's nationality policy as a model for conflict resolution?

5.5 The settler states of North America and the Indians: 205 self-governance instead of tutelage?

5.6 Significant differences between multinational and settler states 
6 The Imperative of Genocide Prevention and Elimination

6.1 Genocide alert and early warning system 214

6.2 Early action: the creation of a rapid 220 reaction mechanism

6.3 Prosecution and deterrence 221

6.4 Enforcing international law - new institutions, 224 sanctions or interventions?

6.5 Pressure, vigilance and protection 225

6.6 Anticipating dangers - learning lessons from 227 past experiences

Summary and Conclusions $\quad 230$

Notes 234

Bibliography 295

Index 323 


\section{List of Tables}

1.1 ECOR index of mass violence in the decade 1985-94 26

1.2 Frequency and dominance of seven types of conflicts 30 in the decade 1985-94

1.3 Frequency and dominance of conflict types in per cent 31 during the decade from 1985 to 1994

1.4 ECOR index of mass violence 1995-2000 32

1.5 Frequency of types and dominance 1995-2000 40

1.6 Correlates of conflict frequency and dominance 40

$\begin{array}{lll}1.7 & \text { Regional distribution of contemporary mass violence } & 42\end{array}$

1.8 Regional distribution and change $\quad 42$

$\begin{array}{ll}2.1 \text { Social-historical typology of peace } & 77\end{array}$

3.1 Peaceful coexistence through violence prevention and 99 inter-ethnic balance: a typology

3.2 Prevention of violence by peaceful inter-ethnic coexistence: 102 types, instruments and models

3.3 Types and methods of/for crisis prevention and peaceful coexistence

4.1 Official minorities and other ethnic groups: 158 a west European overview

4.2 Minority nationalities in potential EU member states of eastern and southeast Europe

6.1 Systematic overview on genocide prevention: tasks, procedures, institutions and voids. A tool box

6.2 Early warning - escalator box with indicators for alert 


\title{
Foreword
}

\author{
by Johan Galtung
}

This brilliantly conceived and very well researched book is a source of wisdom that will enhance your knowledge and compassion for the human condition. The amount of knowledge conveyed in its pages is amazing. Countless millions who have suffered - mainly but not exclusively at the hands of the West - are given a voice through its well-documented pages. They encounter so much almost endless violence, expressed either in direct violence as eradication or genocide; in structural violence as colonialism, manifest in today's reservations; or in cultural violence as an unbounded arrogance, bolstered by the sense of being chosen by God, by being socially at the peak of evolution and by being economically favoured by the Market. Nevertheless, a message of hope shines through, already expressed in the title: Structural Prevention of Ethnic Violence. The message carried by the word 'prevention' is very clear: act before violence breaks out, not afterward.

A nationality, as defined by Scherrer, is a "nation without its own state but in search of statehood'. The United Nations should have been their trade union, if we take the name literally. As we know 'Members are States'; the UN is a trade union of states with one clear, common interest: do not touch our borders. With 200 states, at least 2000 nations but only 20 nation-states (to give some indication) there could be hundreds of wars to fight - some of which have taken place since 1945 - unless we learn to better handle the nationality question before hostilities break out.

Indeed, there may be nations within nations and so forth also seeking statehood. The term 'structural' carries another clear and important message: the arrangement must be solid, long lasting (although nothing is eternal), acceptable, self-sustaining - and as little dependent on outside 'guarantees' as possible. Again, act beforehand, pre-emptively, preventively, not as a cure after major violence has already struck.

A key instrument is 'self-determination', but, as Scherrer points out, it tends to 'protect states rather than peoples'. Moreover, there has been an unfortunate tendency on all sides to cast the struggle in terms of a (shameful) status quo versus independence where the broader term 'autonomy' may be more useful. As Scherrer says: 'Prevention through appropriate autonomy arrangements and generous nationality policies is not only cheaper than intervention, they are, in fact, the only real, ideal method when it comes to dealing constructively with the problem of ethno-national difference.' Adding: 'The development of concepts of structural prevention of genocide and mass violence are among the noblest tasks of peace research.' I could not agree more. 
While the subject matter of medicine is to build health, avoid disease and specifically pandemics, the essence of peace research is to build peace, avoid violence and specifically genocide, defined as the extermination of people because they are identified as belonging to a certain category. One such category is 'nation', others categories are gender, class, race, citizen.

A generally accepted fact is that people want to be governed by their own kind, which is what autonomy is all about, from its lowest to its highest levels of articulation. Deny them that and there will be trouble. Our task now is to expand the spectrum of responses to that challenge. And Scherrer's book is indispensable in that search. 


\section{Preface}

Prevention of destructive violence is a political imperative for the twentyfirst century. Since World War II, more than 300 wars have taken place worldwide - most of them, until the end of the 1980s, in the Third World. Claims of a number of nation-states in regard to the nationalities, which they claim as their own citizens and in regard to ethnic minorities and indigenous peoples, seem to become increasingly aggressive in times of changes. On the view presented here, this state of affairs is, in empiricalcum-historical terms, the most dangerous potential and actual source of conflicts and wars both in the former Third World and, since 1989-90, in the former nominally socialist multinational states. Almost two-thirds of current wars are susceptible to 'ethnic' interpretation. It was only when the Janus-like countenance of nationalism reappeared in Europe that the media and broad sections of the public in the West became aware of this global trend towards ethno-nationalism, of which there had been evidence since the period of decolonization. This belated nationalism reviewed the situation left behind by the colonial world-order. Its duality has to do with an inherent dichotomy between liberation and oppression, between emancipation and barbarity.

The global trend towards an increase in intra-state conflicts and a decrease - if not near disappearance - of the classic Clausewitzean war between states has grown steadily over the last few decades. At the end of the millennium there was no interstate conflict, after the bloody war and fratricide between Ethiopia and Eritrea was stopped and UN peacekeepers deployed in December 2000, but - dependent on the criteria employed there are several dozen other violent conflicts. Their main incompatabilities reflect intra-state conditions but the violence they produce does often spill-over borders. We witness a multiplicity of actors in some complex new conflicts (with the Congo and Sudan being the best examples). Different types of contemporary intra-state conflicts can be observed; their dominant characteristic being either anti-regime or ethno-nationalistic, followed by inter-ethnic wars - mostly without state actors being involved - and gang wars and warlordism, which were named 'postmodern wars' (despite the fact that this conflict type has a longer history). There are some decolonization conflicts; the last one to explode was East Timor. The list of conflict types would not be complete without the most deadly one: genocide and other forms of non-war mass violence. Terrorist conflicts, which in the form of international gang wars have gained much attention since 11 September 2001, are neither a new phenomenon nor a particularly 
deadly form of mass violence. The death toll is relatively low; in 2001 they might have caused 0.2 per cent of all conflict-related fatalities.

Those conflict types suited to ethnic interpretation - with ethnicity as the mobilizing force - seemed to grow fastest, although they have been prominent for quite some time. Increases in violent ethno-nationalist conflicts have been observed in the wake of a number of phases of decolonization. Ethno-national conflicts of a violent kind are both products and causes of colonial creation and of the inherent instability of new states. Thus, ethnonationalism is a response to serious ongoing crises; its primary cause, the struggle against the neo-colonial state, has strong structural aspects and, therefore, a truly global spread. However, the level of conflict varies considerably in the different regions of the world. As the example of the CIS shows, the structure and dynamics of the process of fragmentation in the East followed its own rules and differed significantly from the situation in the South.

Any attempt to clarify or resolve sub-national conflicts must be preceded by the realization that existential questions relating to the survival of an ethnic group are not factors that are open to negotiation but essential prerequisites to dialogue. There are a number of highly destructive forms of interaction between states and nations/nationalities resulting in the exclusion and persecution of national groups that have not yet been subject to systematic investigation and for which the international community has not yet developed any consistent policy. This was demonstrated with devastating clarity in the case of the genocide in Rwanda in 1994. The crime of genocide not only calls for prevention but for its elimination. Genocide prevention requires different means other than the prevention of ethnic violence in general and ethno-nationalism in particular.

The political-cum-humanitarian concern to find ways of avoiding violent forms of ethno-nationalism from below and ethnicization from above leads on to the questions of (1) how ethnic and cultural difference can be understood and acknowledged; (2) how destructive forms of interaction between states and nations or nationalities can be prevented; and (3) which institutions, legal measures and policies are most appropriate for that purpose. At the beginning of 1993, former UN secretary-general Boutros-Ghali wrote, very appositely, that it was simpler and cheaper to tackle wars preventively than to try to put a stop to hostilities that had already broken out.

The main problems politicians face in promoting preventive measures and policies are three-fold: (1) the unspectacular and long-term character of many such measures makes them not very attractive if quick results are required; (2) the difficulty in measuring their effectiveness adds to confusion about the subject matter; and (3) a number of rather diverse institutions, measures and policies have preventive characteristics but often remain disengaged or partially implemented. 
In preventing violence there are no 'easy solutions'. The great diversity of cultural and political characteristics exhibited by different types of society produce, correspondingly, different types of claims to autonomy and regulatory mechanisms, ranging from cultural autonomy through territorial self-governance to de facto sovereignty. Protection of ethnic and national minorities by means of a variety of arrangements for autonomy did not begin until the twentieth century, triggered by a worsening of the so-called 'minorities problem' as a result of revolutions and the regroupings that had occurred in the wake of the two world wars.

Too little account has been taken of the nationality policies of certain multinational states when it comes to looking for methods of prevention and dealing with protracted and bloody ethno-national conflicts. Many states have been able to pursue active and successful policies of prevention by making concessions and negotiation involving some element of nationality policy. Others have - often with limited success - used similar tactics to try to resolve armed conflicts that have already escalated. Nationality policies are generally not considered to be solutions to conflicts that are smouldering or have already erupted. Some procedures aim more at containment, or pose the nationality question in a purely socio-political context. But such policies are part of the problem. A detailed comparison ought to be made of the different approaches to nationality policy pursued by selected states such as Denmark, Canada, the USA, the CIS/Russian Federation, China, India, Australia, Brazil, Colombia, Panama, Nicaragua and Ethiopia.

During field research done in the 1980s and early 1990s in two deadly conflict areas (Nicaragua and Ethiopia), solutions - although not ideal ones, as in Nicaragua, or very partial ones, as in Ethiopia - were developed by the local actors themselves. This led me to think about forms of 'structural prevention' of violence, 'structural' in the sense that new frameworks and institutions are created to avert possible direct violence and reduce structural violence, such as discrimination against non-dominant groups. I am deeply indebted to Johan Galtung, who developed the concept of 'structural violence' in the 1970s, based on his path-breaking distinction between direct personal violence (massacres or war) and structural violence (that is, poverty kills). Galtung also reflected on cultural violence, for example values that promote and/or justify violence and superiority complexes that result in aggressive attitudes. Structural prevention aims at ending repression and injustice which is ingrained in state policies and underdevelopment and is also an inherent in the cultural attitudes of many dominant groups.

The contribution of systemic peace research is underestimated. The activities involved range from initiatives by popular local and regional movements to the elaboration of norms and legal instruments within the framework of international and universal organizations. Efforts to change a violence promoting framework through disarmament, controls and bans 
on arms production and trade, demobilization and the strengthening of civil society have often been neglected in the debate about how to deal with or prevent violent conflicts. Work on macro-themes seem to have little effect. Yet partial successes such as the ban on the production of antipersonnel landmines is a crucial step on the path to a more peaceful world.

The underdeveloped state of political and institutional consultancy in peaceful dispute settlement by third parties, or 'go-betweens' in the case of protracted 'ethnic' conflicts, is lamentable. Conflict mediation and facilitation in such conflicts undoubtedly can be successful as an instrument of international politics and should not be left solely to state and inter-state actors. But efforts at go-between mediation by civil actors and initiatives for transforming violent ethno-national and other ethnic conflicts are arduous and hold little attraction for the media.

Against the background of media discovery of the ethnic, and of the general inadequacy of research into the forgotten conflicts of the Third World, more studies should aim to outline and compare various regional and local attempts at conflict resolution within the framework of state policies on minorities and nationalities, to link these up with evolving provisions in international law and human rights and situate them within the international system. The role of multilateral regimes and of the international community in preventing and resolving violent conflicts should be discussed more systematically. Furthermore, more attempts should be made to give a thorough conceptual account of the phenomenon of ethnicity, to work out elements of a theory of modern genocides as well as of 'new wars' and ethno-nationalism, to investigate the latter's causes, to distinguish its many different manifestations, to highlight its political potential as an opposition force, to analyze its structural characteristics and the driving forces behind its militarization and to set the phenomenon of 'ethnic' conflict in a global context. These various aspects can be illustrated by means of examples from four different continents.

This can be read as a call for the reorientation of peace and conflict research towards the 'real existing' conflict formations and for the intensification of international attempts to find methods of preventing and resolving conflict. One factor that is of major importance in the prevention of ethnic and national conflicts is the extension not only of international norms and standards of protection for non-dominant minorities and indigenous peoples but also of the rights of these groups in regard to autonomy and self-governance. In the current debate, normative and structural dimensions of 'conflict prevention', (what is meant is the prevention of violence) are often neglected in favour of more activist and technical approaches. This contradicts the fact that techniques of preventive multitrack diplomacy (such as mediation, facilitation, good offices, arbitration and so on) and other forms of peaceful conflict settlement by go-betweens 
are - in regard to their overall effectiveness - of secondary importance when compared with a long-term policy for the prevention of violent inter-ethnic and other intra-state conflicts. Therefore, the proliferation of states since 1990 is seen by some observers as a form of 'conflict resolution' and by others as a dangerous fragmentation and a slide into chaos.

The account given here of applied forms of self-governance is the fruit of several years of field research in ethno-national war zones and of collaboration with representatives of indigenous and endangered nations/nationalities. To provide a global comparison of nationality policies based on a set of evaluative qualitative criteria for self-governance agreements is something that can only be attempted in outline here. For some of the cases mentioned, the author can call not only on a wealth of documentation, but also on first-hand information and personal on-the-spot observation.

A further study critically reviews the activities undertaken by international humanitarian organizations in ethnic conflicts and also the efforts of the UN Human Rights Commission to work out minimum standards for the rights of minorities and indigenous peoples. The observations on multilateral regimes are confined, for the most part, to the 'human dimension' that is to say, to human rights mechanisms and minority rights issues. New paths in this direction have been embarked on within the framework convention of the Council of Europe, which laid great emphasis on the protection of national minorities and the creation of the institution of a High Commissioner for National Minorities within the OSCE. However, speculations about the transposability of such (limited) European 'models' must be viewed with scepticism. Legal instruments are not sufficient in themselves in promoting good relations between different communities on the ground. In addition to standard-setting activities (for example the Framework Convention for the Protection of National Minorities of Council of Europe), confidence-building and other measures at grassroot levels aimed at increasing tolerance and understanding between people belonging to different ethnic groups, are required. Reflection on increasing calls for the UN (or NATO) to become involved, or to intervene militarily, in war zones and areas of conflict since the early 1990s, makes clear the primary need for structural prevention and for an expansion in the choice of non-military options. To round off this part of the discussion, a few observations are made about a possible new role for the United Nations.

This choice of objectives necessitates moving far beyond a narrowly defined standpoint. As a field of study, ethno-nationalism embraces the disciplines of ethnology, sociology, folklore, the humanities, human geography, political science, international relations, and constitutional and international law. At present, the needs created by interdisciplinary cooperation have still only limited institutional possibilities corresponding to (or conflicting with) them. The use of various categories and concepts from 
other disciplines is a necessity in this area of study, but it does not in itself constitute interdisciplinarity.

Rigid subject-based division, with its differing perspectives and traditional areas of operation, has led to a fragmentation of the research-field and makes the prospect of any kind of understanding appear dim. The objective cannot be 'to know a little bit about everything'; what we need to do, rather, is to flesh out those issues and methods that have to do with current social problems or can be brought into some kind of relation with them. The separate disciplines can only be linked to current issues (such as intra-societal and cultural conflicts) when peace and conflict research has completed the process of reorientation that has been on the agenda since 1990. Peace research has to develop its communication skills before being able to promote issue-centred dialogue between the various disciplines involved. But establishing an interdisciplinary dialogue is a very demanding process. Where the networking indeed functions well, it does so only on a discrete basis. Up to now the peace research network has been a little too structured and very much tied to individuals. In terms of practical application, the outreach of peace research is almost completely restricted to conferences, workshops, the occasional public debate, and - a trend that is no doubt likely to greatly increase any attempt to link all continents in the near future - the internet. More influential to public awareness are mass media reports on wars or violence occurring in 'far-away places', which often include one-minute interviews with peace researchers who usually disagree with each other.

In the body of peace research there is still little regard to the fact that the distribution of wars has changed radically in the past twentieth century and that today almost all major conflicts are intra-state (civil wars and domestic genocides). Only a few institutions have programmes on intra-state conflicts, its causes and the peace strategies specifically designed to influence internal conflict. Systematic research on the various forms of prevention of violence, peaceful settlement of disputes and constructive transformation of latent and violent conflicts is still largely underdeveloped.

Surprisingly very few social anthropologists and sociologists are contributing to increase the competence of peace and conflict research - and, most importantly, its application by activists in peace-building and practitioners of conflict management - in regard to the types of civil wars driven by ethno-national, cultural and in some cases economic factors, or struggles for power. This lack of interest seems to prevail despite (or because?) of such research being a highly topical and fundamentally problem-oriented field. Its themes and methods overlap with similarly problem-oriented areas of research dealing with major contemporary issues such as migration, racism and multiculturalism. The preoccupation with such neglected topical problem areas nevertheless has become a new feature of studies, concepts and analyses of a growing body of research since the end of the cold war and more so since the mid 1990s. 
The analytical framework of this study certainly cannot be constructed within the boundaries of a single discipline. While discipline based research in the humanities and social sciences continues to have an important task to do, the specializations of the individual disciplines must be linked up to themes and issues of general interest. It is in this area that peace and conflict research could exercise one of its most important functions within the academic enterprise. Because of its quasi-inherent orientation towards problems and topical events, it would be in a position to make a major contribution to the kind of reforming and innovatory thrust which is needed to respond to the new challenges of the present age and set the relationship of the sciences to society on an appropriate footing.

However, extending the frame of reference - for example, to include the political sciences and jurisprudence - also results in certain problems being 'imported'. As is demonstrated by the axiomatic presupposition of states as the primary political actors, this can become an obstacle. Such axioms tend towards exclusivity and towards the exclusion or neglect of the part played by other actors. In my view, an exclusively state-centred orientation is to be rejected. Nations without states look for a revision of international law that will secure them protection and guarantees within the community of nations. For indigenous peoples and for many endangered nationalities, the quest to secure an improvement in their legal status and recognition as political entities is a matter of survival. Not only has the concept of state sovereignty long since been undermined by the international enmeshment that has occurred in politics, the economy and communications. We live in the third era of globalization. The principle of non-intervention in internal affairs is now negated by the existence of international regimes and multilateral organizations: by the UN system; by powerful institutions (such as the IMF and World Bank); by the financial markets, the activities of international banks and multinational corporations and the omnipresence of the electronic media, with their disregard for national frontiers. The territorial integrity of the 195 states is increasingly being called into question by the existence of between 3000 and 10,000 ethnically distinct entities. Many nationalities aspire to separate statehood or respond to the particular configuration of power by seeking a free association with existing states; some already enjoy a form of autonomy or self-governance, others have fought for and secured a de facto autonomy based on arms.

For a long time, subjects such as 'the nation', 'nationalism', or 'ethnicity' were taboo in many parts of the world. As long as these ideas were being used in relation to the most remote areas of the Third World, the threshold of inhibition within the scientific community remained relatively low; but 'too bold' application of them to their own societies was regarded as well nigh outrageous. Not long ago, ideas such as 'ethnic conflict' or 'ethno-nationalism' were avoided as far as possible or, depending on the situation and area of the world, were replaced by misleading euphemistic (or demonizing) 
expressions such as 'miscellaneous conflicts', 'ethnic cleansing', or 'tribalism'. Because of the stigmatization of the subjects mentioned, there has been little incentive to try to fill the gaps in research on ethno-nationalism and on the ways of preventing or resolving such conflicts. This whole area has been left to the journalists, propagandists and bar-room politicians.

As a result of the frequently perverted depiction of the ethnic factor in the press and under the influence of the media's confused categorization of horrendous images of war, the scientific discourse on this subject is scarcely audible and remains largely ignored. The need to come up with new definitions and to make what may be unusual connections will place interested readers in the position of having to question well-established views. This study is part of an overdue attempt to address one of the major issues of our time from a multi-dimensional interdisciplinary perspective.

I should like to preface this work with some words of thanks to friends and colleagues. I am very grateful to Johan Galtung, Ted Robert Gurr, Kader Asmal, the late Bernard Nietschmann, the late Howard R. Berman, Judy Butler, Mohamed A. Teisir, Kumar Rupesinghe, Jannis Markakis, Mohamed Sahnoun, Julian Burger, Norbert Ropers, Michael van Walt, Matthias Stiefel, Joseph Nsengimana, Stephen Ryan, Hans Petter Buvollen, Willem J. Assies, Patricia van Nispen, Christoph Schwager, Alexander Sutter, Anton Ivanov, Regine Mehl, Martin Bondeli, Lorenz Löffler, Dieter Senghaas and Tobias Debiel for their comments and criticisms, and especially to Siglinde Gertschen and Sigi Szczepanski for suggestions and for reading through the manuscript, and to Margaret Clarke, for her careful and competent translation of large sections of my German texts.

I am particularly indebted, also, to all the representatives and champions of indigenous and endangered peoples whose acquaintance I have made over the last dozen years. They have opened my eyes to the profoundly desperate situations, the sufferings and the fighting spirit that exist on the periphery of the world's states and systems. Their resistance and their struggle for their historic rights and for the right to be different, deserve our sympathy and support. 


\section{List of Abbreviations}

ACP-EU African, Caribbean, Pacific - European Union

ADF

Allied Democratic Forces (West Uganda, DRC)

AFB

Arbeitsgruppe Friedensforschung Bonn/Peace Research Information Unit Bonn (http://www.bonn.iz-soz.de/afb)

AFDL Alliance des Forces Démocratiques de Libération (DRC)

AGKED Arbeitsgemeinschaft Kirchlicher Entwicklungsdienste (FRG)

AGP

AI

Assam Gana Parishad (India)

AIM

Amnesty International (London)

AIPP

American Indian Movement

AIS

Asian Indigenous Peoples Pact (Bangkok)

AJSU

ANC

Armée Islamique du Salut (Algeria, wing of FIS)

ANUC

All Jharkhand Students Union (India)

APEC

African National Congress (South Africa)

APPRA

Asociación Nacional de Usarios Campesinos

ASEAN

Asia Pacific Economic Co-operation

Asia-Pacific Peace Research Association

ASEN

Association of South-East Asian Nations

ASSR

Association for the Study of Ethnicity and Nationalism

Berghof

Autonomous Soviet Socialist Republic

BIA

Center for Constructive Conflict Management (Berlin)

BJP

Bureau of Indian Affairs (USA)

BRA

Bharatiya Janata Party (India)

CARICOM

Bougainville Revolutionary Army (Papua New Guinea)

CCA

Caribbean Common Market

CCM

Carter Center, Atlanta (www.cc.emory.edu/)

CDR

Chama Cha Mapinduzi (Tanzania)

CHSG

Coalition pour la Défense de la République (Rwanda)

CIS

Conference of Heads of State and Government (OAU)

Commonwealth of Independent states (12 states,

all former Soviet Republics except for the Baltic states www.cis.minsk.by)

CISA Congreso Indígena del Sur de América

CMG Conflict Management Group (Harvard)

CMM Chattisgarh Mukti Morcha (India)

CoE Council of Europe

COPRED Consortium on Peace Research, Education \& Development (http://www.igc.apc.org/copred/)

CORPI Coordinación Regional de Pueblos Indígenas 
$\mathrm{CPB}$

Communist Party of Burma

CPC Conflict Prevention Centre (OSCE)

CPSID Convention on the Peaceful Settlement of International Disputes

CRP Conflict Resolution Program (Carter Center, Atlanta, Georgia)

CSCE Conference on Security and Co-operation in Europe (later OSCE)

CSE Communità di Sant'Egidio, Rome, Catholic INGO

CSO Committee of Senior Officials (OSCE)

DAB Democratic Alliance of Burma

DANIDA Danish International Development Agency

Democide website on Democide (www2.hawaii.edu/ rummel/)

DEZADDC Swiss Agency for Development Cooperation, Berne

DGFK

doCIP

DRC

Deutsche Gesellschaft für Friedens- und Konfliktforschung

EBLUL

ECA

$\begin{array}{ll}\text { ECOR } & \text { Ethnic Conflicts Research Project } \\ \text { ECOSOC } & \text { Economic and Social Council (UN) }\end{array}$ Documentation Centre for Indigenous Peoples (Geneva)

Democratic Republic of Congo

European Bureau of Lesser Used Languages

UN Economic Commission for Africa, Addis Ababa (www.uneca.org/)

ECOMOG ECOWAS Cease-fire Monitoring Group I and II (in Liberia and Sierra Leone)

ECOWAS Economic Community of West African States

EDF European Development Fund (European Union; development fund)

ELN Ejército de Liberación Nacional (Colombia)

EPCPT European Platform for Conflict Prevention and Transformation (network of European NGOs, www.euconflict.org/)

EPLF Eritrean People's Liberation Front

EPRDF Ethiopian Peoples Revolutionary Democratic Front (gov. party, former liberation movement)

ESN Ethnic Studies Network

EZLN Ejército Zapatista de Liberación Nacional/Zapatista National Liberation Army (Mexico, Chiapas)

FARC Fuerzas Armadas Revolucionarias de Colombia

FGN Federal Government of Nagaland (India)

FIER Foundation for Inter-ethnic Relations

FIS Front islamique du Salut (Algeria)

FLEC Frente de Libertação do Enclave de Cabinda (Angola)

FMLN Frente Farabuno Martí para la Liberación Nacional (El Salvador) 


\begin{tabular}{|c|c|}
\hline FRELIMO & $\begin{array}{l}\text { Frente de Libertacão de Moçambique/Liberation } \\
\text { Front of Mozambique }\end{array}$ \\
\hline FRETILIN & $\begin{array}{l}\text { Frente Revolucionara de Timor Leste Independiente/ } \\
\text { Revolutionary Front of Independent East Timor) }\end{array}$ \\
\hline FSLN & Frente Sandinista de Liberación Nacional (Nicaragua) \\
\hline FSO & foreign-state occupation \\
\hline GfBV & Gesellschaft für bedrohte Völker (Göttingen, FRG) \\
\hline GIA & Groupe Islamique Armé (Algeria) \\
\hline GNLF & Gorkha National Liberation Front (India) \\
\hline HCNM & High Commissioner on National Minorities (OSCE) \\
\hline HDI & $\begin{array}{l}\text { Human Development Index (UNDP, annual reports, } \\
\text { http://www.undp.org/hdro/) }\end{array}$ \\
\hline HRFOR & $\begin{array}{l}\text { Human Rights Field Operation in Rwanda (1994-8, } \\
\text { by UNHCHR) }\end{array}$ \\
\hline HRW & Human Rights Watch (http://www.hrw.org/) \\
\hline HSFK & Hessische Stiftung Friedens- und Konfliktforschung \\
\hline IA & International Alert (http://www.international-alert.org) \\
\hline IBRD & World Bank (http://www.worldbank.org/) \\
\hline ICAR & $\begin{array}{l}\text { Institute for Conflict Analysis and Resolution, George } \\
\text { Mason University (Fairfax Virginia) }\end{array}$ \\
\hline ICC & International Criminal Court (to be established) \\
\hline ICC & Inuit Circumpolar Conference \\
\hline ICCPR & International Covenant on Civil and Political Rights \\
\hline ICESCR & $\begin{array}{l}\text { International Covenant on Economic, Social and } \\
\text { Cultural Rights }\end{array}$ \\
\hline ICG & International Crisis Group (Brussels) \\
\hline ICJ & International Court of Justice (The Hague) \\
\hline ICON & Internal Conflicts and their Resolution (IPRA group) \\
\hline ICRC \CICR & $\begin{array}{l}\text { International Committee of the Red Cross/Comite } \\
\text { International de la Croix-Rouge (Geneva, www.cicr.org) }\end{array}$ \\
\hline ICTR & $\begin{array}{l}\text { International Criminal Tribunal for Rwanda } \\
\text { (Arusha, http://www.ictr.org/) }\end{array}$ \\
\hline ICTY & $\begin{array}{l}\text { International Criminal Tribunal for the Former Yugoslavia } \\
\text { (The Hague, www.icty.or/) }\end{array}$ \\
\hline IDP & internally displaced person \\
\hline IFSH & $\begin{array}{l}\text { Institut für Friedensforschung und Sicherheitspolitik } \\
\text { (Hamburg) }\end{array}$ \\
\hline IGCC & $\begin{array}{l}\text { University of California Institute on Global Conflict } \\
\text { and Co-operation (http://www-igcc.ucsd.edu) }\end{array}$ \\
\hline IITC & International Indian Treaty Council (San Francisco) \\
\hline IJC & International Court of Justice (The Hague) \\
\hline ILO & International Labour Organization (Geneva) \\
\hline ILRC & Indian Law Resource Center \\
\hline IMEMO & Institute for World Economy (Moscow) \\
\hline
\end{tabular}


IMF International Monetary Fund (http://www.imf.org/)

INCORE Initiative on Conflict Resolution and Ethnicity (www.incore.ulst.ac.uk/)

INEF Institut für Entwicklung und Frieden/Institute for Development and Peace (University of Duisburg)

INGOs International Non-Governmental Organizations

INN International Negotiation Network (Carter Center, Emory Univ., Atlanta, Georgia)

IPA International Peace Academy (www.ipacademy.org/)

IPRA International Peace Research Association

IRIPAZ Instituto de Relaciones Internacionales y de Investigación para la Paz (Guatemala)

IUPIP International University of Peoples' Initiative for Peace (http://www.unimondon.org/iupip)

IWGIA International Work-Group for Indigenous Affairs

JEEAR Joint Evaluation of Emergency Assistance to Rwanda (international consortium, coordinated by DANIDA)

KANU Kenya African National Union

KIO/KIA Kachin Independence Organization/Army (Burma)

KLA Kosovo Liberation Army (Federal Republic of Yugoslavia, also known as UCK)

KNU Karen National Union (Burma)

LLDC least developed country

LNO Lahu National Organization (Burma)

LRA Lord's Resistance Army (North Uganda, Sudan)

LTTE Liberation Tigers of Tamil Eelam (Sri Lanka)

MCAC Mediation, Conciliation and Arbitration Committee (OAU)

MCC Maoist Communist Centre (India)

MCTK Movimiento Campesino Tupak Katari (Bolivia)

MFDC Mouvement des Forces Démocratique de la Casamance (Senegal)

MIAND Ministry for Indian Affairs and Northern Development

MINURSO United Nations Mission for the Referendum in Western Sahara

MNF Mwalimu Nyerere Foundation (Dar es Salaam)

MNRD Mouvement National Républicain pour la Démocracie (Rwanda)

MONUC Mission d'Observation des Nations Unies au Congo/UN Observer Mission to Congo-DR

MRTA Movimiento Revolucionario Túpac Amaru (Peru)

MSF Médecins Sans Frontières (humanitarian aid organization, emergency medical assistance; www.msf.org)

MTA Mong Tai Army (Burma)

NAC National Aboriginal Conference

NADECO National Democratic Coalition (Nigeria) 
NAFTA North American Free Trade Agreement

NAILS National Organization of Aboriginal and Islander Legal Services

NAM Non-Aligned Movement

NCGUB National Coalition Government of the Union of Burma

NCIV Nederlands Center for Inheemse Volken

NNA Neutral and Non-Aligned states

NNC Naga National Council (India)

NSCN National Socialist Council of Nagaland (India)

OAS Organization of American States

OAU Organization of African Unity (www.oau-oua.org/)

ODIHR Office for Democratic Institutions and Human Rights (OSCE)

OECD Organization for Economic Cooperation and Development (Paris)

OLF Oromo Liberation Front (Ethiopia)

OSCE Organization for Security and Co-operation in Europe (formerly CSCE)

ÖSFK Österreichisches Studienzentrum für Frieden und Konfliktlösung

OW One World (network, 250 NGOs www.oneworld.org/)

OXFAM British development, advocacy and relief agency; http://www.oxfam.org

PBI Peace Brigades International (www.igc.apc.org/pbi/)

PCA Permanent Court of Arbitration (The Hague)

PGI Prevent Genocide International www.preventgenocide.org

PHR Physicians for Human Rights (medical forensic experts; http://www.phrusa.org/)

PIOOM Interdisciplinary Research Programme on Causes of Human Rights Violations, Leiden, Netherlands (www.fsw.leidenuniv.nl/www/w3_liswo/pioom.htm)

PLA Peoples Liberation Army (India)

PRIO International Peace Research Institute Oslo (http://www.prio.no/)

PSLF Palaung State Liberation Front (Burma)

RENAMO Resistência Nacional Moçambicana

RGN Revolutionary Government of Nagaland (India)

RPF Rwandese Patriotic Front

RSS Rashtriya Swayamsevak Sangh (India)

RUF Revolutionary United Front (Sierra Leone)

SAARC South Asian Association for Regional Co-operation

SADC Southern African Development Community (Regional organization, 1992; 14 states from South Africa to Congo; http://www.sadcexpo.org/)

SADCC Southern African Development Coordination Conference (Regional organization, 1980, frontline states against Apartheid South Africa, 1992 SADC) 
SIDA Swedish International Development Agency

SIPRI Stockholm International Peace Research Institute

SLORC State Law and Order Council (Burma)

SPLM/A Sudanese People's Liberation Movement/Army

SSA Shan State Army (Burma)

SSP Shiv Sena Party (India)

SUA Shan United Army (Burma)

TFF Transnational Foundation for Future and Peace Research, Lund (www.transnational.org/sitemap.html)

TNC transnational corporation

Transcend Peace \& Development Network (www.transcend.org)

TRC Truth and Reconciliation Commission (South Africa)

UCK Albanian name for Liberation Army of the Kosovo (Federal Republic of Yugoslavia)

ULFA United Liberation Front of Assam (India)

UN DPI UN Department of Public Information (various websites, e.g. http://www.reliefweb.int )

UN DPKO United Nations Department for Peacekeeping Operations (http://www.un.org/Depts/dpko/)

UNAMIR United Nations Assistance Mission for Rwanda (I, UN troops sent Oct. 1993, pulled out in April 1994, 2.500; II sent mid 1994, 5.500)

UNCTAD United Nations Conference on Trade and Development

UNDP United Nations Development Programme (http://www.undp.org/)

UNESCO United Nations Educational, Scientific \& Cultural Organization (http://www.unesco.org/)

UNHCHR United Nations High Commissioner for Human Rights

UNHCR United Nations High Commission for Refugees (http://www.unhcr.ch/)

UNICEF United Nations Children's Fund (www.unicef.org/)

UNITA Uniao Nacional para a Independencia Total de Angola/National Union for Total Independence of Angola

UNLF United National Liberation Front (India)

UNPO Unrepresented Nations and Peoples Organization (The Hague)

UNREO United Nations Rwanda Emergency Office

UNRISD United Nations Research Institute for Social Development (Geneva)

UNU United Nations University (Tokyo; www.unu.edu/)

UNWGIP United Nations Working Group on Indigenous Populations (Sub 2, UNCHR)

US-AID Development agency of USA (http://198.76.84.1/)

USC United Somali Congress (Somalia South)

USIP United States Institute for Peace (www.usip.org/) 
US-SD US State Department, Bureau of African Affairs

UWSA United Wa State Army (Burma)

WCIP World Council of Indigenous Peoples

WF State of the World Forum (www.worldforum.org/)

WNO Wa National Organization (Burma)

WPI World Policy Institute (www.worldpolicy.org/)

WSP War-torn Societies Project (UNRISD, UN Geneva)

YATAMA Yapti Tasbaya Masrika (Miskitu Indian movement, Eastern Nicaragua) 